\title{
Depthwise variation of carbon, nitrogen and biogenic silica in sediment from lakes of Pokhara Valley, Nepal
}

\author{
U.R. Khadka ${ }^{1} 2^{*}$, AL. Ramanathan ${ }^{2}$ \\ ${ }^{1}$ Amrit Campus, Tribhuvan University, Kathmandu, Nepal \\ ${ }^{2}$ School of Environmental Sciences, Jawaharlal Nehru University, New Delhi, India
}

\begin{abstract}
Phewa and Begnas lakes in Pokhara Valley are playing important roles in ecological, economic, cultural and aesthetic aspects. However, due to increase in anthropogenic pressure and activities in the lake catchment, the nutrient load in the lakes has been substantially increased. The growth of algae and phytoplankton is largely dictated by carbon $(\mathrm{C})$, nitrogen $(\mathrm{N})$, phosphorus $(\mathrm{P})$, and silica $(\mathrm{Si})$ availability. Moreover, the increase in $\mathrm{P}$ and $\mathrm{N}$ loading leads to greater diatom production resulting in the accumulation of biogenic silica (BSi) in sediments. Thus, variation in $\mathrm{C}, \mathrm{N}$ and $\mathrm{BSi}$ in sediment reflects the nutrient dynamics in the lake. In this connection, $\mathrm{C}, \mathrm{N}$ and $\mathrm{Si}$ concentration serves as an indicator for growth of algae, including diatom, phytoplankton productivity, and overall phytoplankton efficiency. The preceding researches have mostly explained limnological characteristics and plankton diversity studies. Hence, information about sediment characteristics associated with nutrient loading and eutrophication seems yet to be wanting. The present study has been carried out to evaluate vertical variation of $\mathrm{C}, \mathrm{N}$ and $\mathrm{BSi}$ in core sediments of the Phewa and Begnas lakes. The $\mathrm{C}$ and $\mathrm{N}$ was determined by $\mathrm{CHNS}$ analyzer and BSi was extracted by wet-alkaline digestion method and determined by molybdosilicate method. The result revealed increase in $\mathrm{C}, \mathrm{N}$ and BSi contents toward the surface sediments compared to underlying layers suggesting increased rate of accumulation in recent deposits. The magnitude of $\mathrm{C}, \mathrm{N}$ and BSi was higher in city-ward core of Phewa Lake explaining the influence of the urban inputs to the lake. This result suggests that in these lakes the scale of eutrophication has been increasing with time, which demands special emphasis on conservation plan and integrated watershed management strategy to preserve the natural integrity and beauty of the lakes.
\end{abstract}

Key words: Diatom, Eutrophication, Nutrient loading, Phytoplankton

\section{Introduction}

Lakes, reservoirs and wetland are among the most easily available freshwater resources suitable for human consumption. They have ability to retain, store, clean and evenly distribute water which are essential components of regional and global water balance. In addition, they influence many aspects of ecology, economy and human welfare (Lehner \& Doll, 2004). Moreover, they are major regulators in the $\mathrm{C}, \mathrm{N}, \mathrm{P}$ and $\mathrm{Si}$ cycles through various processes: sedimentation of detrital organic matter, production of autochthonous organic matter, and precipitation of carbonates and evaporites (Meybeck, 1995). As the effects

*Corresponding author, email address: udhabk@yahoo.com and changes in the environment are recorded in lake sediments it behave as natural archives of climate and environment-related proxies in response to anthropogenic and climatic changes (Battarbee et al., 2002; Choudhary et al., 2009; Vreca \& Muri, 2006). This makes the high altitude lakes suitable for paleo-climatic reconstruction and modeling with respect to anthropogenic and climatic variations (Meybeck, 1995; Sommaruga-Wograth et al., 1997; Wake \& Mayewski, 1996). Thus, lakes and reservoirs have distinct characteristics. However, compared to other water bodies, the volume of water contained in lake is very limited (Shiklomanov, 1993). 
Further, the mountain lakes are considered as an extreme environment because of their small and sensitive ecosystems with rapid flushing rate (Vreca \& Muri, 2006). They respond quickly to any direct anthropogenic influence or humaninduced changes in the catchment and thus, they are in ecologically marginal situation. The climatic changes and anthropogenic activities have significantly influenced the mountain lakes over many centuries (Gopal, 2005). Thus, knowledge about lakes and reservoirs is of prime importance for assessments of present and future resources, for climate change modeling and for large-scale studies of the environment, biodiversity, health, and agricultural stability (Lehner \& Doll, 2004).

In the Pokhara Valley, to understand the various aspects of lakes, many researchers (Ferro \& Swar 1978; Gurung et al., 2006; Gurung et al., 2010; Hickel, 1973; Jones et al., 1989; Khadka \& Ramanathan, 2012; Rai 2000a, 2000b; Swar \& Fernando, 1979, 1980) have carried out several studies in Phewa and Begnas Lakes. Thus, among others, these two lakes are considered as the better-studied lakes in the Pokhara Valley as well as in Nepal. However, most of the previous works have covered plankton studies, and limnological investigations. For example: Hickel (1973) studied the limnology and phytoplankton composition. Ferro and Swar (1978) carried out bathymetric survey. Swar and Fernando $(1979,1980)$ worked on cladocera and limnetic crustacean zooplankton. Swar and Gurung (1988) worked on impact of introduction of exotic carps on fish harvest. Jones et al. (1989) evaluated ionic composition of waterbodies. Rai (2000a) studied limnology and seasonal changes in phytoplankton and zooplankton. Rai (2000b) evaluated the natural food for planktivorous fish. Gurung et al. (2006) evaluated phytoplankton primary production, chlorophyll$\mathrm{a}$, and nutrient concentration in the water-column. Likewise, Gurung et al. (2010) studied abundance and nutrient limiting growth rate of heterotrophic bacterio-plankton. Khadka and Ramanathan (2012) assessed the composition of major ions in Begnas Lake. These preceding researches appeared so far in scientific sphere indicate that he works on sediment, particularly on the distribution of $\mathrm{C}, \mathrm{N}$, and $\mathrm{BSi}$ is yet lacking Hence, in this study, attempt has been made to evaluate the $\mathrm{C}, \mathrm{N}$ and BSi contents in Phewa and Begnas lakes sediments to fill up the lacunae. In this connection, this is one of the first studies of its kind which could be useful for the better understanding and management of the lakes.

\section{Materials and Methods Study area}

The Pokhara Valley, spread around the midstream of the Seti Khola (river/stream) in the Western Development Regior of the Lesser Himalayan zone of Nepal (Fig. 1), is uniquely characterized by the combination of features: panoramic mountain Annapurna, magnificent lakes Phewa, Begnas anc Rupa as well as the turbulent river Seti Khola with deep gorge (Fig. 2). Many lakes viz. Gunde, Khaste-Neureni, Dipang, Maidi, Kamal Pokhari which existed earlier have almost lost their lake features and exhibit merely a wetlanc characteristics (Fig. 2). Among the various lakes in the valley the Phewa and Begnas Lakes have been selected for the present study because of their key role in local ecosystem, economy, severity of the water quality problems and their location, the former at the heart of the city and the latter a little far from the city.

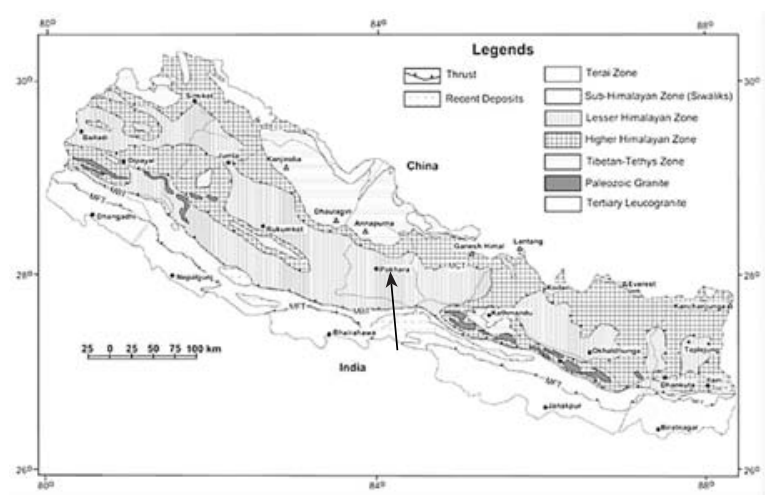

Fig. 1 Geological Map of Nepal showing Pokhara Valley (pointed by arrow) in the Lesser Himalaya (modified after Dahal \& Hasegawa, 2008)

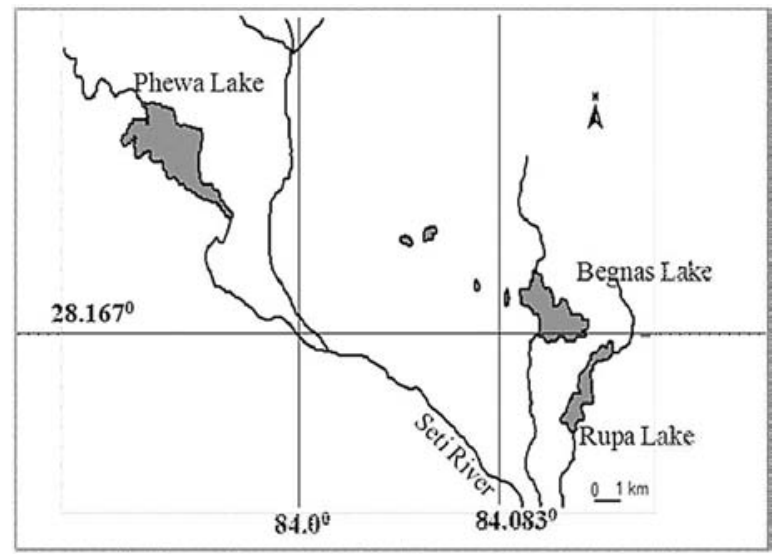

Fig. 2 Map of Pokhara Valley showing distribution of lakes (black shaded areas) (modified after Hickel, 1973) 


\section{Geology}

The Pokhara Valley represents an intermontane fluvial basin spread around the midstream of the Seti Khola in the Lesser Himalaya. It is filled by large volume of layered clastic deposts such as gravel, silt and clay of quaternary age brought from the Annapurna mountain range (Yamanaka et al., 1982). The lithology constitutes structurally weak, low-medium grade Precambrian to early Cambrian grey phyllitic schists, talc-rich red phyllite schists (Ross \& Gilbert, 1999; Rowbotham \& Dudycha, 1998), quartzite schists inter-bedded with grey phyllite schists, carbonaceous conglomerate (Impat, 1980), gneiss, granite, quartzite and schist (Gautam et al., 2000).

Department of Mines and Geology, Nepal (1998) reported that the watersheds constitute Pre-Cambrian to Palaeozoic gritty phyllite and quartzite, gneiss with inter-bedded schist. Moreover, the Quaternary alluvial fan deposits constitute loamy to sandy gravel, sand and silt, fine grained materials, soft to stiff calcareous silty clay to clayey silt inter-fingering with dark carbonaceous clay, clayey silt, grey moderately to weekly compact silty to sandy gravel, and light grey to yellowish grey highly calcareous cemented very hard conglomerate with main constituents limestone, gneiss, quartzite and schist.

Due to presence of the easily soluble calcareous material (25-65\% by volume) in the clastic sediments, splendid river terraces and deep gorges are carved by the Seti Khola and its tributaries. The karst structures like subsurface flow channels, solution cavities; sinkholes, pinnacles, solution chimneys etc. are widely developed both at the surface and underground (Gautam et al., 2000).

\section{Sample collection and analytical method}

The sediment samples were collected from shallower but permanently wet areas of the lakes. In order to assess depthwise variation of $\mathrm{C}, \mathrm{N}$, and $\mathrm{BSi}$ contents the core sediment were collected. From Phewa Lake, two cores, one from westward side (PC1) i.e. inlet side, and another from east-ward side (PC2) i.e. city-ward side, were collected (Fig. 3A). Likewise, from Begnas Lake only one core $(\mathrm{BC})$ from the inlet side was taken (Fig. 3B). All the cores were taken manually by inserting a long polyvinylchloride (PVC) pipe and pushing them down into the lake bottom sediment. Each core was cautiously sliced into $5 \mathrm{~cm}$ segments avoiding mixing. The core sediment samples were transferred to the clean zipped polythene bags and carefully brought to the laboratory. The sediment samples were first air dried at room temperature, then oven dried at $80{ }^{\circ} \mathrm{C}$ for about 24 hours. The samples were ground to fine powder using mortar and pestle, and stored until analysis. The sediment samples were again oven dried prior to weighing for the analysis.

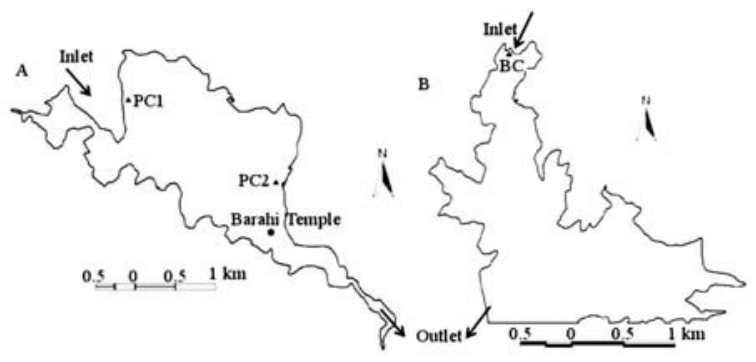

Fig. 3 Map of core sediment sample location (A Phewa Lake, B Begnas Lake)

The total carbon (TC) and total nitrogen (TN) was determined in CHNSO analyzer (Euro EA elemental analyzer- 3000 Series). Biogenic silica was determined according to Struyf et al. (2005). In this method, $50 \mathrm{mg}$ of dry sediment sample was treated with $40 \mathrm{ml} 0.1 \mathrm{M}$ freshly prepared $\mathrm{Na}_{2} \mathrm{CO}_{3}$ solution and incubated at $80^{\circ} \mathrm{C}$ in a water bath. The tubes were kept well shaken during the incubation. Then, sub-samples were taken after 3, 4 and 5 hours. Silicon concentration in the extract was determined in the form of $\mathrm{SiO}_{2}$ by molybdosilicate method (APHA, 2005). Bigogenic silica was calculated by extrapolating the linear line through the three extraction points in a time-extracted silica plot and taking intercept value (DeMaster, 1981).

\section{Results and Discussion}

The result shows the $\mathrm{C}, \mathrm{N}$ and $\mathrm{BSi}$ vary with the lake and depth of the core sediment. The data obtained during the study are discussed in separate subheading for $\mathrm{C}, \mathrm{N}$ and $\mathrm{BSi}$.

\section{Carbon}

Carbon is one of the most common elements in living organisms. The atmospheric carbon dioxide is the main source of $\mathrm{C}$ for all life forms. It is slightly soluble and thus absorbed in water. In lakes and reservoirs dissolved $\mathrm{CO}_{2}$ is utilized by algae and phytoplankton through photosynthesis, making it available for other forms of life. The burial of these life forms contribute $\mathrm{C}$ to the sediment. In Phewa Lake, the $\mathrm{C}$ content in PC1 core varied from 0.13 to $1.50 \%$, and in PC2 core, it varied from 0.27 to 2.29 \% (Table 1, Fig. 4). Likewise, in Begnas Lake core (BC), it varied from 0.26 to $1.10 \%$ (Table 1, Fig. 5). The core sediment from both the lakes demonstrated increase in $\mathrm{C}$ content towards the up core sediments compared to the underlying layers (Table 1, Fig. 4, 5) suggesting an increase in $\mathrm{C}$ load in recent deposits. 
Table 1 Total carbon (\%) in lake sediments

\begin{tabular}{cccc}
\hline \multicolumn{4}{c}{ Carbon } \\
\hline Depth $(\mathbf{c m})$ & PC1 & PC2 & BC \\
\hline $0-5$ & 1.497 & 2.286 & 1.103 \\
$5-10$ & 0.993 & 1.51 & 1.048 \\
$10-15$ & 0.389 & 1.41 & 0.4 \\
$15-20$ & 0.424 & 1.284 & 0.4 \\
$20-25$ & 0.302 & 1.012 & 0.38 \\
$25-30$ & 0.318 & 0.451 & 0.39 \\
$30-35$ & 0.254 & 0.442 & 0.308 \\
$35-40$ & 0.284 & 0.412 & 0.27 \\
$40-45$ & 0.13 & 0.41 & 0.26 \\
$45-50$ & -- & 0.416 & -- \\
$50-55$ & -- & 0.309 & -- \\
$55-60$ & -- & 0.267 & -- \\
\hline
\end{tabular}

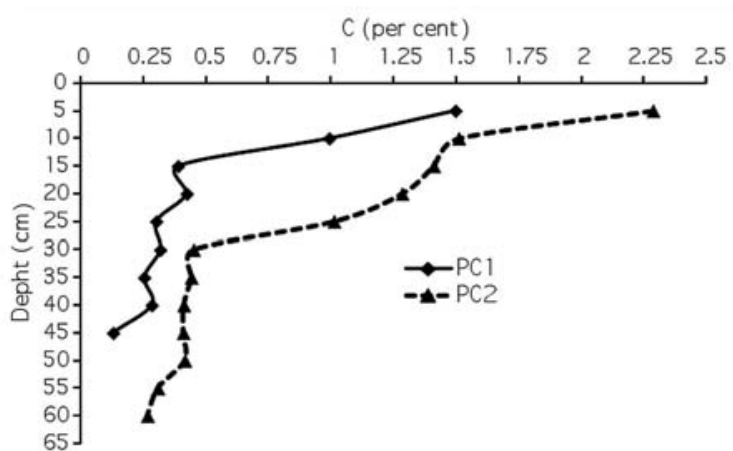

Fig. 4 Distribution of carbon in core sediment from Phewa Lake

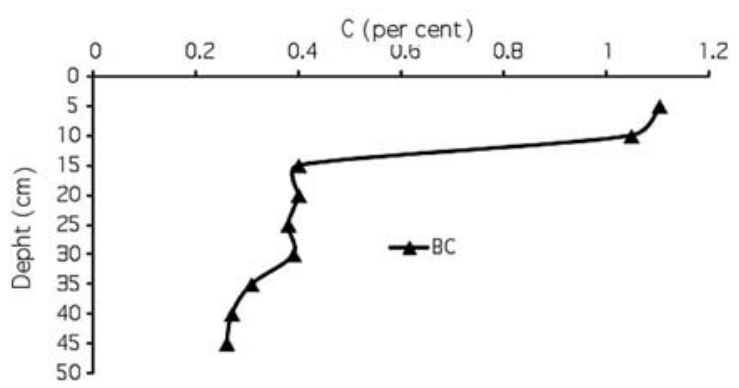

Fig. 5 Distribution of carbon in core sediments from Begnas Lake
Table 2 Total nitrogen (\%) in lake sediments

\begin{tabular}{lccc}
\hline \multicolumn{4}{c}{ Nitrogen } \\
\hline Depth (cm) & PC1 & PC2 & BC \\
\hline $0-5$ & 0.168 & 0.264 & 0.107 \\
$5-10$ & 0.091 & 0.168 & 0.094 \\
$10-15$ & 0.032 & 0.137 & 0.037 \\
$15-20$ & 0.04 & 0.129 & 0.037 \\
$20-25$ & 0.028 & 0.098 & 0.036 \\
$25-30$ & 0.028 & 0.042 & 0.036 \\
$30-35$ & 0.026 & 0.038 & 0.033 \\
$35-40$ & 0.026 & 0.037 & 0.024 \\
$40-45$ & 0.014 & 0.037 & 0.023 \\
$45-50$ & -- & 0.035 & -- \\
$50-55$ & -- & 0.034 & -- \\
$55-60$ & -- & 0.027 & -- \\
\hline
\end{tabular}

\section{Nitrogen}

Nitrogen is a constituent of DNA, and thus an essential element. In soil and sediments, it can be found in the form of nitrates and nitrites. The application of N-containing fertilizers and industrial release has substantially increased the nitrogen to the environment. In Phewa Lake, $\mathrm{N}$ content in PC1 core ranged from 0.01 to $0.17 \%$ and in PC2 core it ranged from 0.03 to $0.11 \%$ (Table 1, Fig. 6). In both the locations, the $\mathrm{N}$ content increased in up core sediments. In Begnas Lake core sediment (BC), the $\mathrm{N}$ content varied from 0.02 to $0.11 \%$ which also increased toward the surface compared to deeper sediment (Table 2, Fig. 7). All the three cores showed increased loading of $\mathrm{N}$ contents. Further, in Phewa Lake, the N content is higher in PC2 core which explains the urban influence in city-ward sediments (Table 2, Fig. 6).

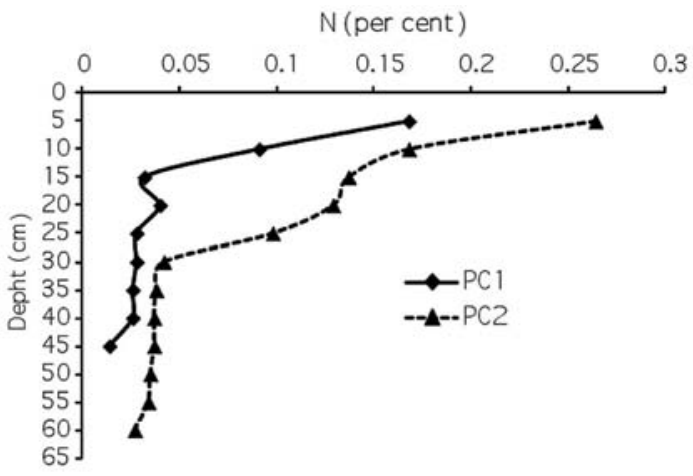

Fig. 6 Distribution of nitrogen in core sediment from Phewa Lake 


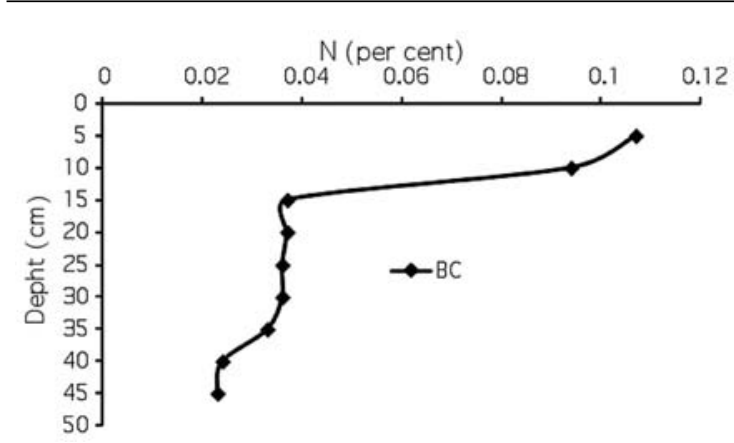

Fig. 7 Distribution of nitrogen in core sediments from Begnas Lake

\section{C:N ratio}

$\mathrm{C} / \mathrm{N}$ atomic ratio is often used to distinguish between algal and land-plant origin of sedimentary organic matter (Galman et al., 2008; Meyers, 1994; Routh et al., 2004, 2007). Algae typically have atomic $\mathrm{C} / \mathrm{N}$ ratio between 4 and 10, whereas vascular land plants have $\mathrm{C} / \mathrm{N}$ ratio of ${ }^{3} 20$. This distinction arises from the absence of cellulose in algae and its abundance in vascular plants. Selective degradation of organic matter components during early diagenesis has the potential to modify $\mathrm{C} / \mathrm{N}$ ratio of organic matter in sediments (Meyers, 1994). In Phewa Lake, the $\mathrm{C} / \mathrm{N}$ atomic ratio in PC1 core varied between 10.39 and 14.18, and in PC2 core, it varied between 10.1 and 13.57. In the core from Begnas Lake (BC), it varied between 10.89 and 13.19. The results elucidate that the organic matter in Phewa and Begnas Lakes is primarily derived from the in-lake phytoplankton production. However, the ratio $(>10)$ is also indicating increasing contribution from terrestrial plants source. The $\mathrm{C} / \mathrm{N}$ ratio in Sattal Lake of Kumaun Himalaya has been reported to vary between 11 and 14 suggesting a similar source of organic matter (Choudhary et al., 2009).

\section{Biogenic silica}

Biogenic silica (BSi) is mainly found in the shells of several different aquatic organisms, generally in the form of $\mathrm{SiO}_{2} * \mathrm{nH}_{2} \mathrm{O}$. It is soluble at time-scales ranging from days to years (Hurd, 1983; Werner, 1976). Silicon in soil is availabe for plant uptake as monosilicic acid $\left(\mathrm{H}_{4} \mathrm{SiO}_{4}\right)$ originating from the dissolution of crystalline silicate minerals and weathering of BSi (Carnelli et al., 2001). Living organism that use and/or deposit silica include bacteria, radiolarian, diatoms, plants (rice husks, horsetail shoots), insects (mandibles) and, as a trace element in the higher animals (Coradin et al., 2004). Diatoms incorporate dissolved silica into their frustules and as there are no significant organic compounds containing silicon, its regeneration occurs by simple chemical dissolution of the diatom shells (Iler, 1979).
In lake, the increased nutrient inputs such as $\mathrm{P}$ and $\mathrm{N}$ stimulate algal production and eventually eutrophication (Kenney et al., 2002; Verschuren et al., 2002). The dominance of one of the classes of algae viz. diatoms is dictated largely by $\mathrm{P}$ and Si availability (Brady \& Brugam, 2002). Thus, increased P loading leads to greater diatom production, which causes an accumulation of BSi in the sediments (Conley et al., 1993). Therefore, BSi concentration serves as an indicator of the diatoms productivity, and overall phytoplankton efficiency (Peinerud et al., 2001). Moreover, increased diatom production may lead to Si deficiency to limiting levels, eventually causing a shift in phytoplankton from diatoms to other algae that have no silica requirement (Schelske et al., 1983). Colman and Bratton (2003) observed that the increase in BSi concentration in Chesapeake Bay sediments were associated with human impacts in the surrounding watershed. Thus, BSi accumulation in sediment is often used as a proxy for nutrient loading and algal production in aquatic systems (Pensa \& Chambers, 2004).

Table 3 Biogenic silica $\left(\mathrm{g} \mathrm{kg}^{-1} \mathrm{dw}\right)$ content in the core sediments

\begin{tabular}{lccc}
\hline & \multicolumn{3}{c}{ Biogenic silica } \\
\hline Depth (cm) & PC1 & PC2 & BC \\
\hline $0-5$ & 2.616 & 5.438 & 2.452 \\
$5-10$ & 2.148 & 4.185 & 2.416 \\
$10-15$ & 1.092 & 3.683 & 1.832 \\
$15-20$ & 1.051 & 2.678 & 1.365 \\
$20-25$ & 0.749 & 1.595 & 1.994 \\
$25-30$ & 0.900 & 1.683 & 1.681 \\
$30-35$ & 0.314 & 1.288 & 1.219 \\
$35-40$ & 0.421 & 1.391 & 0.793 \\
$40-45$ & 0.282 & 1.283 & 0.467 \\
$45-50$ & -- & 0.763 & 0.787 \\
$50-55$ & -- & 1.169 & 0.404 \\
$55-60$ & -- & 1.002 & - \\
\hline
\end{tabular}

The sediment samples collected from the Phewa and Begnas lakes revealed variation in BSi content with respect to lakes and depth of the sediment. In Phewa Lake, the core from the west-ward side (PC1) showed BSi variation between 0.28 $\mathrm{g} \mathrm{kg}^{-1} \mathrm{dw}$ and $2.62 \mathrm{~g} \mathrm{~kg}^{-1} \mathrm{dw}$. While, the sediment from the east-ward or city-ward side (PC2) showed BSi variation between $0.76 \mathrm{~g} \mathrm{~kg}^{-1} \mathrm{dw}$ and $5.44 \mathrm{~g} \mathrm{~kg}^{-1} \mathrm{dw}$ (Table 3, Fig. 8). The core sediment from both the locations of Phewa Lake demonstrated that the biogenic silica concentration increased in up-core sediment. Moreover, in the city-ward core (PC2), the magnitude of BSi concentration is higher than the westward (PC1) core suggesting the influence of the urban input 
on the diatom growth (Table 3, Fig. 8). Similarly, the core sediment samples collected from the north-ward or inlet side of Begnas Lake $(\mathrm{BC})$ revealed the BSi variation between $0.40 \mathrm{~g} \mathrm{~kg}^{-1} \mathrm{dw}$ and $2.45 \mathrm{~g} \mathrm{~kg}^{-1} \mathrm{dw}$ illustrating increase in BSi content towards the surface of the core (Table 3, Fig. 9). The results indicate that lake environment supported the increased growth of diatoms in recent periods suggesting increased inputs of nutrients like P and N, eventually causing eutrophication. This result suggests that both the lakes are prone to increased nutrient loading from the catchment area (Schelske et al., 2006). In both the lakes, the increase in phosphorus and nitrogen loading in recent period has also been supported by the findings of various workers (Jones et al., 1989; Khadka \& Ramanathan, 2012; Rai, 2000a).

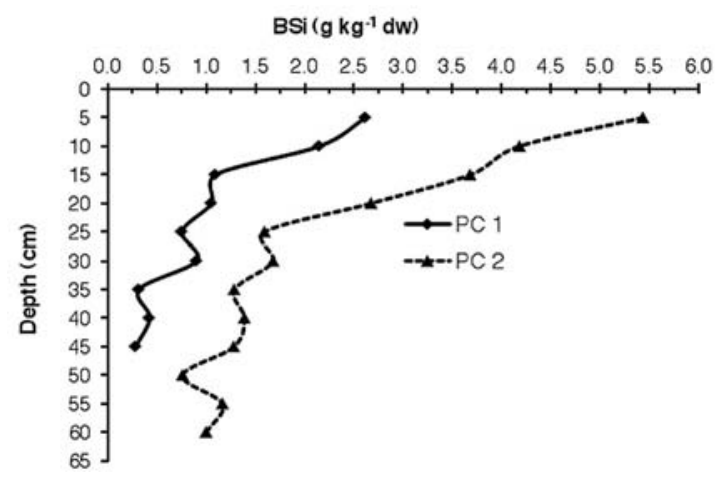

Fig. 8 Biogenic silica in the core sediments from Phewa Lake

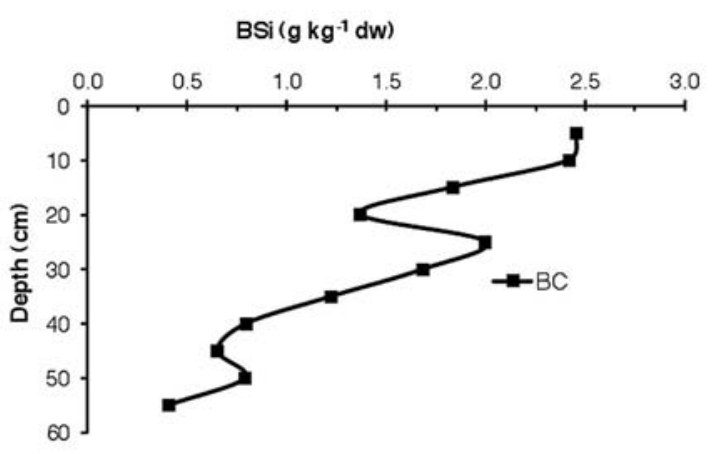

Fig. 9 Biogenic silica in the core sediments from Begnas Lake

\section{Conclusion}

The Phewa and Begnas lakes are the natural heritage playing important roles in maintaining local ecology, biodiversity, economy, and aestheticism. However, for the last few decades these lakes have been threatened with water quality deterioration and siltation problems leading to eutrophication due to increase in population, urbanization, land-use changes, tourism and other anthropogenic activities.

The present study revealed that $\mathrm{C}, \mathrm{N}$ and BSi concentrations increased towards the surface sediment compared to deeper layer suggesting an increase in nutrient loading in recent deposits leading to eutrophication with the passage of time. The magnitude of $\mathrm{C}, \mathrm{N}$, and BSi in city-ward sediment of Phewa Lake was higher than the west-ward core as well as core from Begnas Lake suggesting effect of urban/ anthropogenic influence in the lake. Therefore, in order to preserve the natural integrity and beauty of these lakes, the management strategies should focus on curbing nutrients loading from point and non-point sources including anthropogenic and urban inputs along with mitigation of siltion problem.

\section{Acknowledgements}

The authors are grateful to School of Environmental Sciences, Jawaharlal Nehru University, New Delhi, for providing facility to carry out the work. The first authors (UR Khadka) expresses his sincere gratitude to the Amrit Campus, Institute of Science and Technology, Tribhuvan University, and University Grants Commission-Nepal for granting leave and providing partial support, respectively. The authors are also thankful to Fisheries Research Station, Pokhara, Nepal for its assistance during the sampling.

\section{References}

APHA (2005). Standard methods for the examination of water and waste water, 21st ed. New York, American Public Health Association.

Battarbee, R.W., Thompson, R., Catalan, J., Grytnes, J.A., \& Birks, H.J.B. (2002). Climate variability and ecosystem dynamics of remote alpine and arctic lakes: the MOLAR project. Journal of Paleolimnology, 28, 1- 6.

Berner, E.K., \& Berner, R.A. (1996). Global environmental: water, air and geochemical cycles. Englewood Cliffs, Prentice-Hall.

Brady, K., \& Brugam, R.B. (2002). Phosphorus and silica recycling in Cougar Lake, a small Illinois reservoir.Joumal of Freshwater Ecology, 17, 19-26.

Carnelli, E. (1976). Simultaneous automated determination of chloride, nitrite, nitrate, and ammonia in water and waste water. Water Air and Soil Pollution, 5, 339-348.

Choudhary, P., Routh, J., \& Chakrapani, G.J. (2009). An environmental record of changes in sedimentary organic matter from Lake Sattal in Kumaun Himalayas, India. Science of Total Environment, 407, 2783-2795. 
Colman, S.M., \& Bratton, J.F. (2003). Anthropogenically induced changes in sediment and biogenic silica fluxes in Chesapeak Bay. Geology, 31, 71-71.

Conley D.J., Schelske, C.L., \& Stoermer, E.F. (1993). Modification of the biogeochemical cycle of silica with eutrophication. Marine Ecology Progress Series, 101, 179-192.

Coradin, T., Lopez, P.J., Gautier, C., \& Livage, J. (2004). From biogenic silica to biomitic silica. Comptes Renddus Palevol, 3, 443-452.

Dahal, R.K., \& Hasegawa, S. (2008). Representative rainfall thresholds for landslides in the Nepal Himalaya. Geomorphology, 100, 429-443.

DeMaster, D.J. (1981). The supply and accumulation of silica in the marine environment. Geochimica et Cosmochimica Acta, 45, 1715-1732.

Department of Mines and Geology (1998). Engineering and Environmental Geological Map of Pokhara Valley. Department of Mines and Geology, Government of Nepal.

Ferro, W., \& Swar, D.B. (1978). Bathymetric maps from three lakes in the Pokhara Valley (Nepal). Journal of Institute of Science and Technology, Tribhuvan University, Katbmandu, Nepal, 1, 177-188.

Gälman, V., Rydberg, J., de-Luna, S.S., Bindler, R., \& Renberg, I. (2008). Carbon and nitrogen loss rates during aging of lake sediment: changes over 27 years studied in varved lake sediment. Limnology and Oceanography, 53, 10761082.

Gautam, P., Pant, P.R., Ando, H. (2000). Mapping of subsurface karst structure with gamma ray and electrical resistivity profiles: a case study from Pokhara Valley, Central Nepal. Journal of Applied Geophysics, 45, 97-110.

Gopal, B. (2005). Identification of lakes for conservation and restoration (Final Report). New Delhi, National River Conservation Directorate, Ministry of Environment and Forest, Government of India.

Gurung, T.B., Dhakal, R.P. Husen, Md. A., \& Jones, J.R. (2010). Abundance and nutrient limiting growth rate of heterotrophic bacterio-plankton in Himalayan foot hill Lake Phewa, Nepal. Lakes and Reservoirs: Research and Management, 15, 53-61.

Gurung, T.B., Dhakal, R.P., \& Bista, J.D. (2006). Phytoplankton primary production, chlorophyll-a, and nutrient concentration in the water column of mountainous Lake Phewa, Nepal. Lakes and Reservoirs: Research and Management, 11, 141-148.

Hickel, B. (1973). Limnological investigations in Lakes of Pokhara Valley, Nepal. International Review of Hydrobiology, 58, 659-672.
Hickel, B. (1973b). Phytoplankton in two ponds in Kathmandu Valley, Nepal. International Review of Hydrobiology, 58, 835-842.

Hurd, D. (1983). Physical and chemical properties of siliceous skeletons. In S. Aston (Ed.), Silicon geochemistry and biogeochemistry (pp. 187-244). London, Academic Press.

Iler, R.K. (1979). The chemistry of silica. New York, WileyInterscience.

Impat, P. (1980). Phewa Tal watershed soil map. Integrated Watershed Management Project, Nepal.

Jones, J.R., Knowlton, M.F., \& Swar, D.B. (1989). Limnological reconnaissance of water-bodies in central and southern Nepal. Hydrobiologia, 184, 171-189.

Kenney, W.F., Waters, M.N., Schelske, C.L., \& Brenner, M. (2002). Sediment records of phosphorus-driven shifts to phytoplankton dominance in shallow Florida lakes. Journal of Paleolimnology, 27, 367-377.

Khadka, U.R., \& Ramanathan, AL. (2012). Major ion composition and seasonal variation in the Lesser Himalayan lake: case of Begnas Lake of the Pokhara Valley, Nepal. Arabian Journal of Geosciences. doi 10.1007/s12517-012-0677-4.

Lehner, B., \& Doll, P. (2004). Development and validation of a global database of lakes, reservoirs and wetlands. Journal of Hydrology, 296, 1-22.

Meybeck, M. (1995). Global distribution of lakes. In A. Lerman, D.M. Imboden, \& J.R. Gat (Eds.), Physics and Chemistry of Lakes. Berlin, Springer.

Meyers, P.A. (1994). Preservation of elemental and isotopic source identification of sedimentary organic matter. Chemical Geology, 114, 289-302.

Peinerud, E.K., Ingri, J., \& Ponter, C. (2001). Non-detrital Si concentrations as an estimate of diatom concentration in lake sediments and suspended material. Chemical Geology, 177, 229-239.

Pensa, M.A., \& Chambers, R.M. (2004). Trophic transition in a lake on the Virginia coastal plain. Journal of Environ Quality, 33, 576-580.

Rai, A.K. (2000a). Limnological characteristics of Subtropical Lakes Phewa, Begnas, and Rupa in Pokhara Valley, Nepal. Limnology, 1, 33-46.

Rai, A.K. (2000b). Evaluation of natural food for planktivorous fish in Lakes Phewa, Begnas, and Rupa in Pokhara Valley, Nepal. Limnology, 1, 81-89.

Ross, J., \& Gilbert, R. (1999). Lacustrine sedimentation in a monsoon environment: the record from Phewa Tal, middle mountain region of Nepal. Geomorphology, 27, 307-323. 
Routh, J., Meyers, P.A., Hjorth, T., Baskaran, M., \& Hallberg, R. (2007). Sedimentary geochemical record of recent environmental changes around Lake Middle Marviken, Sweden. Journal of Paleolimnology, 37, 529-545.

Routh, J., Meyers, P.A., Gustafsson, Ö., Baskaran, M., Hallberg, R., \& Scholdström, A. (2004). Sedimentary geochemical record of human induced environmental changes in the Lake Brunnsviken watershed, Sweden. Limnology and Oceanography, 49, 1560-1569.

Rowbotham, D.N., \& Dudycha, D. (1998). GIS modelling of slope stability in Phewa Tal Watershed, Nepal. Geomorphology, 26, 151-170.

Schelske, C.L., Stoermer, E.F., Conely, D.J., Robbins J.A., \& Glover, R.M. (1983). Early eutrophication in the lower Great Lakes: New evidence from biogenic silica in sediments. Science, New Series, 222, 320-322.

Schelske, C.L., Stoermer, E.F., \& Kenney, W.F. (2006). Historic low-level phosphorus enrichment in the Great Lakes inferred from biogenic silica accumulation in sediments. Limnology and Oceanography, 51, 728-748.

Shiklomanov, I. (1993). World fresh water resources. In P.H. Gleick (Ed.), Water in crisis: A guide to the world's fresh water resources. New York, Oxford University Press.

Sommaruga-Wograth, S., Koinig, K.A., Schmidt, R., Sommaruga, R., Tessadri, R., \& Psenner, R. (1997). Temperature effects on the acidity of remote alpine lakes. Nature, 387, 64-67.

Struyf, E., Van Damme, S., Gribsholt, B., Middelburg, J.J., \& Meire, P. (2005). Biogenic silica in tidal freshwater marsh sediments and vegetation (Schelde estuary, Belgium). Marine Ecology Progress Series, 303, 51-60.

Swar, D.B., \& Fernando, C.H. (1979a). Seasonality and fecundity of Daphnia Lumholtzi Sars in Lake Phewa, Nepal. Hydrobiologia, 64, 261-268.
Swar, D.B., \& Fernando, C.H. (1979b). Cladocera from Pokhara Valley, Nepal with notes on distribution. Hydrobiologia, 66, 113-128.

Swar, D.B., \& Fernando, C.H. (1980). Some studies on the ecology of limnetic crustacean zooplankton in Lake Begnas and Rupa, Pokhara Valley, Nepal. Hydrobiologia, 70, 235-245.

Swar, D.B., \& Gurung, T.B. (1988). Introduction and cage culture of exotic carps and their impact on fish harvested in Lake Begnas, Nepal. Hydrobiologia, 166, 277-283.

Verschuren, D., Leavitt, P.R., Brown, E.T., Talbot, M.R., Hecky, R.E., Johnson, T.C., Kling, H.J., \& Edington, D.N. (2002). History and timing of human impact on Lake Victoria, East Africa. Proceedings: Biological Sciences, 269, 289-294.

Vreca, P., \& Muri, G. (2006). Changes in accumulation of organic matter and stable carbon and nitrogen isotopes in sediments of two Slovenian mountain lakes (Lake Ledvica and Lake Plannina) induced by eutrophication. Limnology and Oceanography, 51, 781-790.

Wake, C.P., \& Mayewski, P.A. (1996). Himalayan interdisciplinary Paleoclimate Project. PAGES Workshop report-series, pp. 96-1. 96.

Werner, D. (1976). Silicate metabolism. In D. Werner (Ed.), The biology of diatoms (Vol. 13), Botanical monographs. Oxford London Edinburgh Melbourne, Blackwell Scientific Publications.

Yamanaka, H., Yoshida, M., \& Arita, K. (1982). Terrace landform and Quaternary deposits around Pokhara Valley, Central Nepal. Journal of Nepal Geological Society, 2, 95-112. 